\title{
OAJ and Wagadu: Towards a Diamond Model of Feminist, Postcolonial Publishing
}

\author{
Mechthild Nagel
}

Center for Gender and Intercultural Studies, SUNY Cortland, POB 2000, Cortland, NY 13045 USA, Mecke.Nagel@cortland.edu, http://web.cortland.edu/nagelm/

\begin{abstract}
This comment reflects on the genesis of an OA non-corporate journal, affiliated with a public university. Wagadu: A Journal of Transnational Women's and Gender Studies emerged from an idealized discussion of open access to a more robust understanding of the pragmatics of visibility, tenure and promotion guidelines. It gives account of the challenge of trying to navigate in ethical ways through the corporate waves of cooptation.
\end{abstract}

Keywords: open access, Global South, Global North, journal ranking, equity

In their article, "The Diamond Model of Open Access Publishing: Why Policy Makers, Scholars, Universities, Libraries, Labour Unions and the Publishing World Need to Take NonCommercial, Non-Profit Open Access Serious," Christian Fuchs and Marisol Sandoval pose the following challenging questions: "What should the role of open access be in the future of academic publishing and academia? How should the future of academic publishing and academia look like? Which reforms of academic policy making are needed in relation to open access publishing?" $(2013,428)$. In this article I reflect on these and other questions by focusing on a journal that I founded over a decade ago. The founding editorial board intended to create a journal that would be centred on concerns of the Global South; at the same time, stakeholders and other considerations such as equity and economic viability guided our subsequent decisions.

\section{The Windy Road Towards Interactivity - With Corporations}

Co-founder Nina Zimnik (Luzern University of Applied Sciences, Switzerland) envisioned that Wagadu would have an interactive platform, allowing for readers' commentaries, blogs, and short film clips. Our web design team lacked the resources to put it in place, but it was a vision that came to be realized with the advent of social media a few years later. Now, Wagadu has a presence on Facebook (yes, a corporate site), and it allows our readers to upload information regarding upcoming conferences, events, and call for papers of interest to fellow readers.

Facebook wasn't the only concession to participate in corporate "commons". We decided to partner with the giant on-demand publisher Xlibris and select special issues are available in paperback copies; one of the books has almost got us enough in royalties to break even. At times, Xlibris will phone me to discuss promotional advertisement packages, potentially costing us thousands of dollars, which we will never recuperate. I always decline because I can count on our free OA website, browsed by thousands of readers, to do the same job. In fact, I will have better results, since it is a focused, mostly academic, readership, specializing in postcolonial scholarship. Additionally, we have a link targeting librarians to purchase our bound Xlibris volumes. We have not yet figured out to use a low-cost way to encourage libraries to purchase the book that they would otherwise routinely buy from academic presses.

Our final corporate concession involved sharing File Transfer Protocol (FTP) data with EBSCO, H.W. Wilson and Proquest, using non-exclusive rights contractual language to incur royalties when readers made use of their search engines. We insisted on open access of the entirety of the journal. Wagadu decided to cooperate with these corporate database owners, 
because European academic contributors asked us that it would bring much needed legitimation as academic journal. Fuchs and Sandoval (2012) note that these corporations in addition to the presses that own online journals have virtual monopoly and garner fantastic profit margins unheard of in other corporate sectors. So, it is ironic that unpaid academic writers and editors have to negotiate contracts with the very neoliberal institutions that Wagadu sets out to criticize. When we explored Wagadu, there were a few OA journals that had a similar scope and reach: Safundi: The Journal of South African and American Studies, JENDA: A Journal of Culture and African Women Studies focusing on work by African feminist scholars, and ProudFlesh: New Afrikan Journal of Culture, Politics and Consciousness. Within the last decade, all three have since gone to subscription-based publishing, as the editor of ProudFlesh notes, "to meet the growing operational cost of production" (n.d.). Both journals, Jenda and ProudFlesh are operated under AfricaResource (http://www.africaresource.com) while Safundi is owned by Taylor and Francis. By contrast, journals supported by universities such as Wagadu have maintained OA status: Feminist Africa, housed by the African Gender Institute, University of Cape Town, prominently features its Creative Commons license, and the International Journal of Women's Studies, supported by Bridgewater State University, Ct, USA, which highlights its philosophy of the Digital Commons as a public good (http://vc.bridgew.edu/about.html).

\section{Genesis}

The journal's name resonates with the name of a Soninke goddess of great strength as well with a legend of West African territoriality:

"Wagadu - the Soninke name of the Ghana Empire - controlled the present-day Mali, Mauritania and Senegal and was famous for its prosperity and power from approximately 300-1076. It constituted the bridge between North Africa, the Mediterranean and Middle Eastern worlds and Subsaharan Africa. Ghana gave birth to the two most powerful West African Empires: Mali and Songhay. The modern country of Ghana (former British Gold Coast) derives its name from the Ghana Empire. Legend says that Ghana's power derived from a mythic python, which generated the rich gold deposits and controlled the fortunes of the empire. Year after year the people of Ghana had to offer the most beautiful virgin to the python as a sacrifice. One year, the distressed fiancé of a sacrificial girl took a sword and beheaded the mythic python in a preemptive move. The head flew and crashed into the parts of West Africa that became gold producing regions leading to the rise of the Mali Empire. Ghana fell after seven years of drought and poverty forced the Ghana people, the Soninke, to disperse and adopt exodus as a way of life to this day. Why Wagadu? Wagadu has come to be the symbol of the sacrifice women continue to make for a better world. Wagadu has become the metaphor for the role of women in the family, community, country, and planet. The excerpt below from a Soninke song best summarizes this state of fact: Duna taka siro no yagare npale. The world does not go without women"

(http://appweb.cortland.edu/ojs/index.php/Wagadu/about/editorialPolicies\#focusAndScope).

\section{Accessibility}

The idea of the journal became a reality with a Technology Grant from the State University of New York. In 2003, our technology advisors, Larry Ashley (SUNY Cortland) and web design expert Sabine Groote, who then resided in Berlin, Germany, developed a website format that would be multi-lingually accessible. Given our journal's name, we were particularly interested in African languages. However, the lingua franca remains English, yet we make an effort to translate abstracts into four languages (Chinese, French, Spanish, Portuguese). Alas, very few abstracts have been translated into African languages.

Our first journal issue went live in 2004 with a special issue on "Feminists Confront Empire". We wanted to create space for a journal that creates space for academic and nonacademic activists, and a number of independent scholars and policy writers have published articles with us. As editor-in-chief, I also receive requests from authors, specifying the acceptance rate and verifying a peer-reviewed, anonymous standard protocol for publication. 
The rejection and resubmission rates are quite similar to traditional academic journals. We know of high success rates of our authors attaining tenure and promotion in various academic systems the world over. Given the African connotation of the journal's name, we are fortunate to draw a good percentage of authors from the continent. Yet, I am told that few journals can take pride in having a significant and constant presence of African writers, as Wagadu has been fortunate to do. So, our goal to establish an academic voice and outlet for the global South has been accomplished. Perhaps it is also in part due to our dedication to print articles both in html version as well as pdf format. It would be good if the Directory of Open Access Journals would archive content in html format as well. African academics have not enjoyed access to high-speed Internet connection, and it is critical that they can continue accessing our papers via the html format as well. A snapshot review of one article, by health professor Ben Wodi (of SUNY Cortland) is revealing:

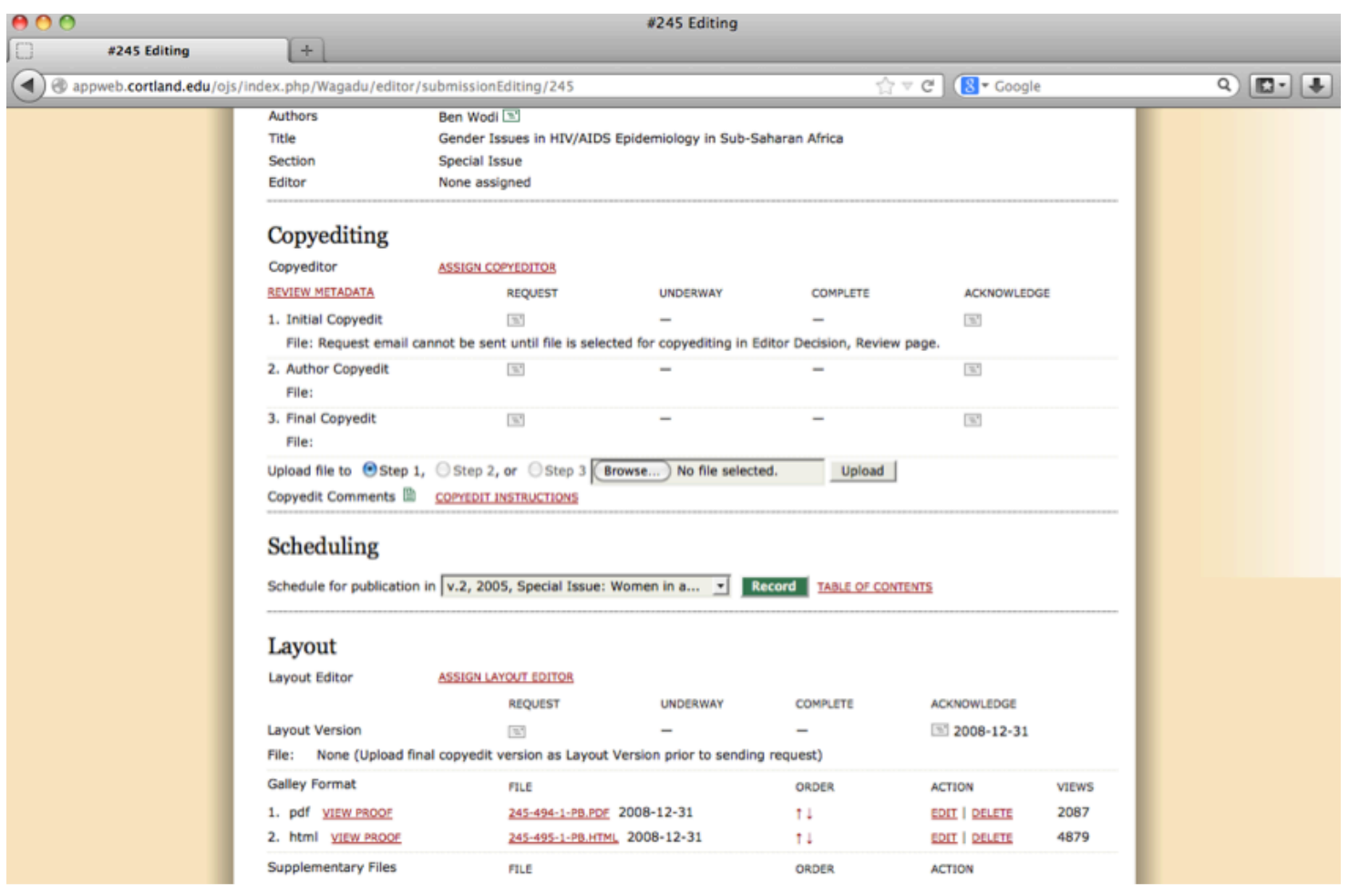

Table 1: Snapshot of article by Ben Wodi (2005)

In comparison to other articles published by Wagadu, Wodi's article on AIDS shows a much higher readership of the article in html than in pdf.

Since 2008, we have utilized the open source software of the Public Knowledge Project (PKP). SUNY Cortland provides webmaster assistance from a full-time IT employee. In theory, the PKP facilitates more interactivity of papers submitted; the advanced platform allows for different roles, e.g. editors, reviewers, copy editors, and authors. It tracks the dates that specific tasks are submitted, with canned letters sent to authors and automatic reminders sent to reviewers and authors. However, we have found that the interactive site is neglected, and more often than not, papers still get reviewed the old fashioned way, via email submissions. Worse, there is endless spam entering my mailbox as editor-in-chief, because the spam filter for signing up as reviewers was not properly activated. Thus, the reviewers' list has become quite worthless, as it is too difficult to parse through the thousands of spam emails. Before we switched to PKP, a previous platform allowed us to review the readership profile from different geographical locations. At that time, I recall that the readership was drawn mostly from the Anglo-American Global North. So, in that sense, Wagadu, as a mostly English-oriented journal, is not unique. 


\subsection{Innovative Alliance with Another OA}

Wagadu partnered up with the International Journal of Women's Studies, based at Bridgewater University, to put together a special issue on African women's activism. Both of our journals had a set of editorial team members and once the papers were selected, two different volumes were put together with separate editorials. Wagadu published one set and IJWS published another. Both volumes were collectively put together in a bound volume with Xlibris Press, with both universities sharing the publication costs. The issues can be reviewed at http://appweb.cortland.edu/ojs/index.php/Wagadu/issue/view/36 with the following brief overview: "The authors focus on women's activism throughout Africa within a transnational and cross-cultural context. This edition expands traditional concepts of activism and adds to a broader awareness of how gender is articulated within social movements, governments and other social institutions.

This Volume is a joint production with the Journal of International Women's Studies (JIWS), Vo. 10(1), 2008: http://www.bridgew.edu/SoAS/JIWS/".

However, their university host migrated the website to this one:

http://vc. bridgew.edu/jiws/vol10/iss1/1/.

The joint volume is available from Xlibris:

http://bookstore.xlibris.com/Products/SKU-0058213003/Wagadu-Volume-6-Journal-ofInternational-Womens-Studies-Volume-101.aspx

Wagadu does not have signed contracts such as the Creative Commons Attribution License that allows others to share the work. Instead, we opted for traditional contract language, recommended by legal counsel of Research Foundation of the State University of New York. The Editor-in-chief, in consultation with the board, makes a case-by-case decision whether or not to grant free republishing rights. In general, we give free republications to non-profit presses and those in the Global South. In general, if the author of the article wishes to republish it in a book, she will not be charged. In a rare case, we have also allowed the editor to republish the entire volume for free as part of a bigger anthology project. The contract above alludes to the fact that Wagadu publishes hard copies with Xlibris Press.

\section{Ranking of International Gender Studies Journals}

In 2007, I received an invitation by the European Science Foundation and its division focusing on peer reviewed journals (The European Reference Index for the Humanities, ERIH), to submit Wagadu to a Gender Studies ranking of the best international journals in their respective disciplines. ERIH operates under the auspices of the European Science Foundation (ESF). "Launched in 2002, the ERIH is a list of high-quality humanities journals intended to help identify research excellence in Europe and also serve as a tool of access to this research" (ESF 2011). I decided to participate in this ranking exercise, which took enormous amount of time to research, in part because many at my university saw Wagadu as an "in house" production. If Wagadu would gain appropriate stature, it would be worth it. Furthermore, it would give Wagadu more exposure and visibility internationally. At the same time, I was cognizant of major critiques in Australia of ranking systems of journals that tied promotion criteria to journal rankings (Howard 2011). ERIH is cognizant of the controversies and decided on a different kind of ranking. First of all, it only admitted journals that subjected themselves to this stringent set of standards: "peer review of submissions, an active international editorial board, timeliness of turnaround, openness to new authors, professional bibliographic information..." (ERIH Foreword 2011). The ranking of high quality European journals tries to thwart the US American dominance of ranked, highly visible journals and also feature journals who publish non-English European languages; plus it is noteworthy that authorship by emergent scholars is to be encouraged. Among the final 124 gender studies journals chosen, Wagadu is only one of two African-centred journals - the other being Agenda: Empowering Women for Gender Equity. Very few other journals such as the Indian Journal of Gender Studies were chosen from the Global South - thus the Global North dominance in the publishing field, including OA journals, continues. Wagadu was entered in the INT 2 subcategory, indicating "international publications with significant visibility and influence in the 
various research domains in different countries". INT 1 sub-category is reserved for those journals "with high visibility and influence among researchers in the various research domains in different countries, regularly cited all over the world" (ERIH 2011).

\section{Ranking of International Gender Studies Journals}

So far, SUNY Cortland continues to be committed to host Wagadu as OA journal, raising the reputation of the university. Our editorial team is committed to work to improve user friendliness of the PKP software. In 2011, DOAJ indexed Wagadu, and we hope to enter into an agreement with DOAJ after applying for a certification agreement with SPARC Europe Seal for Open Access Journals. If we get clearing for SUNY lawyers for the SPARC seal, we will pursue the CC-BY license (Creative Commons license) and provide DOAJ with metadata on article level. In general, I believe the future of OA journals is going strong: I was invited in 2011 to present Wagadu to graduate students at Syracuse University, who were encouraged by their librarian professionals to invest in OA publications and deposit their dissertations in the digital commons. There is still quite a bit of apprehension on the value of OA publishing, but, frankly, it will subside. It is as much a matter of convenience from the readers' side as it is ensuring access from the publisher's end: if I need to pay or reach for the interlibrary loan button to get critical information, I would rather seek out an OA article that had the same information. None of our Wagadu board members are paid or get release time for our journal work; workload that is compensated as professional service would be quite helpful. I do not yet envision the longevity of an OA journal being ensured through other institutional settings than the university commons. Corporate platforms taint the editorial integrity of academic freedom; seriously, if I decided to run a special issue on gendered labour in academic presses such as Taylor and Francis, and that conglomerate would own Wagadu - would they really want to publish critiques of their corporate practices?

Just this week, I received an invitation to join a New Zealand journal on governance ethics which proposes the following: "The intent is to regulate academic robustness through a $<20 \%$ acceptance rate but to also allow non-refereed corporate contributions to connect to business leaders as well". I will pass over this invitation in silence.

\section{References}

ERIH. 2011. Foreword. European Science Foundation.

http://www.esf.org/hosting-experts/scientific-review-groups/humanities-hum/erih-european-referenceindex-for-the-humanities/erih-foreword.html

ESF. 2011. European Science Foundation Releases the 2011 Revised Lists of European Research Index for Humanities. ESF News, Announcements \& Press Releases.

http://sandbox.esf.org/media-centre/ext-single-news/article/european-science-foundation-releasesthe-2011-revised-lists-of-european-research-index-for-humanitie.html

Howard, Jennifer. (May 13, 2011). Controversial Journal Rankings in Australia Affect Research Funds and Careers. The Chronicle of Higher Education: A 20.

Nzegwu, Nkiru. 2001. Globalization and the Jenda Journal. Jenda: A Journal of Culture and African Women Studies 1 (1), http://www.jendajournal.com/nzegwu1.html

Wodi, Ben. (2005). Gender Issues in HIV Epidemiology in Sub-Saharan Africa. Wagadu: A Journal of Transnational Women's and Gender Studies 2:

http://appweb.cortland.edu/ojs/index.php/Wagadu/article/view/245/453

\section{About the Author}

\section{Mechthild Nagel}

is co-founder and Editor-in-Chief of Wagadu: A Journal of Transnational Women's and Gender Studies at SUNY Cortland. A professor of philosophy and director of the Center for Gender and Intercultural Studies, she is the author/co-editor of several books: Masking the Abject: A Genealogy of Play (Lexington, 2002), Race, Class, and Community Identity (Humanities, 2000), The Hydropolitics of Africa: A Contemporary Challenge (Cambridge Scholars Press, 2007), Prisons and Punishment: Reconsidering Global Penality (Africa World Press, 2007), Dancing with Iris: The Philosophy of Iris Marion Young (Oxford University Press, 2010), and The End of Prisons: Voices from the Decarceration Movement 
(Rodopi, 2013). Diversity, Social Justice, and Inclusive Excellence: Transdisciplinary and Global Perspectives will appear with SUNY Press, 2014. Dr. Nagel has taught in area prisons (Elmira, 5 Points, Cayuga, McCormick) and established a prison education program at her hometown prison, Fulda, Germany. She is a member of the board of the International Conference on Penal Abolition (ICOPA). She works on justice studies, global feminist studies, Africana philosophy/ethics. Her new manuscript is on Ubuntu ethics. 